\title{
Presence of Brome mosaic virus in Barley Guttation Fluid and Its Association with Localized Cell Death Response
}

\author{
Xin Shun Ding, Christy M. Boydston, and Richard S. Nelson
}

The Samuel Roberts Noble Foundation, Plant Biology Division, P.O. Box 2180, Ardmore, OK 73402.

Accepted for publication 18 January 2001.

\begin{abstract}
Ding, X. S., Boydston, C. M., and Nelson, R. S. 2001. Presence of Brome mosaic virus in barley guttation fluid and its association with localized cell death response. Phytopathology 91:440-448.

Water exits from inside the leaf through transpiration or guttation. Under conditions to promote guttation, surface fluid (guttation fluid) from Brome mosaic virus (BMV)-infected barley, wheat, and maize plants was analyzed for the presence of the virus by biological and serological assays. We also investigated the route by which BMV exited infected cells to the intercellular space of the barley leaf. BMV was detected in guttation fluid from systemically infected barley leaves when the initial viral symptoms were observed on these leaves. The virus was also detected in guttation fluid from systemically infected wheat leaves, but not in maize

leaves showing either systemic necrosis or chlorotic streaks. Interestingly, in BMV-infected barley leaves, but not in maize leaves showing chlorotic streaks, cell death occurred within and adjacent to veins. Staining of xylem and phloem networks in infected barley leaves with fluorescent dyes showed that xylem, and to a lesser extent phloem, were severely damaged and thus became leaky for dye transport. No such damage was observed in BMV-infected maize leaves showing chlorotic streaks. We propose that in infected barley leaves, BMV exits from damaged vein cells (especially the xylem elements), accumulates in intercellular spaces, and then reaches the surface of the leaves through stomata during guttation or transpiration. In nature, BMV may be carried to adjacent plants and cause infection by movement of vertebrate and invertebrate vectors among infected plants exuding guttation fluid.
\end{abstract}

Water escapes plant tissue primarily through transpiration, where intercellular fluid moves to the leaf stomata and water vaporizes (6). In addition, plants can secrete a water fluid, known as guttation fluid, from specialized structures called hydathodes when conditions favor water uptake through the root, but limit transpiration from leaves $(21,52)$. In either case, intercellular fluid originating from xylem appears on the leaf surface. Several previous reports have indicated that guttation fluid from various plant species contained noticeable amounts of micro- and macromolecules $(4,10,28,36,41,54)$. In 1937, Johnson (25) showed that guttation fluid from tobacco plants infected with Tobacco mosaic virus contained the virus. In 1960, Ohmann-Kreutzberg et al. (42) showed that inoculation of healthy barley with guttation fluid from Brome mosaic virus (BMV)-infected barley resulted in systemic infection in these plants. More recently, French and Elder and French et al. $(16,17)$ reported that 13 different viruses were found in guttation fluid from their respective dicotyledonous hosts. However, these studies did not identify the routes by which the viruses moved from inside infected cells to the intercellular space for transport to the surface of leaves.

BMV is the type member of the genus Bromovirus. Its genome is divided among three RNA segments known as RNA1 (3.2 kb), RNA2 (2.9 kb), and RNA3 (2.1 kb) (1). RNA1 and RNA2 segments encode two nonstructural proteins involved in BMV replication $(18,27,29,31,47)$. RNA3 encodes the movement protein and the capsid protein $(2,11)$. BMV infects barley (Hordeum vulgare), wheat (Triticum aestivum), maize (Zea mays), and several other monocotyledonous species in nature (32), and a few dicotyledonous species under laboratory conditions (15).

Corresponding author: X. S. Ding; E-mail address: xsding@ noble.org

Publication no. P-2001-0219-01R

(c) 2001 The American Phytopathological Society
For many years, BMV has been used extensively in studies of virus replication and viral gene expression (22-24,26,34,49, and for review see 50). Less effort, however, has been made to understand how the virus is transmitted in nature (32). BMV is generally considered to be nontransmissible through seeds. Under laboratory conditions, BMV can be readily transmitted to test plants by mechanical inoculation. Several species of beetles (Chaetocnema aridula, Oulema melanopus, and Phyllotreta vittula) and a nematode (Xiphenema diversicaudatum) have also been reported to be vectors for the virus under controlled conditions $(19,45,46,55)$. McKinney (38) demonstrated that humans walking in pastures cause BMV spread among smooth brome and orchard grass plants. However, the relative impact of each of these vectors in BMV epidemiology is unknown $(1,12)$.

In this study, we have collected guttation fluid from systemic leaves of BMV-infected barley, wheat, and maize plants and analyzed them for the presence of the virus with biological and serological assays. We have also analyzed tissue sections from infected barley leaves by immunocytochemical and histochemical techniques to determine locations where BMV exited infected cells and accumulated in intercellular spaces for transport to the surface of the leaf. Results of the study showed that BMV infection in barley cv. Morex resulted in localized cell death within and adjacent to vascular bundles, potentially leading to intercellular export of the virus to the leaf surface. This localized cell death did not occur in infected leaves of maize cv. V35. To our knowledge, cell death in BMV-infected barley has not been reported previously.

\section{MATERIALS AND METHODS}

Plant growth and virus inoculation. Hordeum vulgare L. (cvs. Morex, Callao, and Tam Bar 401), Triticum aestivum L. (cv. Bounty 203A; Magaly R Carhill Hybrid Seeds, Fort Collins, CO), and Zea mays L. (cvs. B73 and V35; USDA-ARS, National Germplasm Resources Program, Beltsville, Maryland and L. C. 
Lane, University of Nebraska, Lincoln, respectively) were used for inoculation of BMV and collection of guttation fluid. Plants were grown inside a growth chamber under the standard condition described previously (14). Two weeks after planting, the third leaf of each barley, wheat, and maize plant was inoculated with crude extract prepared from BMV-infected 'Morex' leaves (1:5, wt/vol) in $0.1 \mathrm{M}$ phosphate buffer, $\mathrm{pH}$ 6.0, or mock-inoculated with phosphate buffer as a control. The inoculated leaves were rinsed with distilled water immediately after inoculation, and the plants were grown inside a growth chamber capable of producing conditions suitable for the appearance of guttation fluid (i.e., hereafter referred to as guttation chamber; Model I-60 DLM; Percival Scientific Inc., Boone, Iowa). To create an environment that favors plant guttation, the temperature inside the guttation chamber was set at $20^{\circ} \mathrm{C}$ (chamber wall temperature) and $10^{\circ} \mathrm{C}$ (water pan temperature), respectively, for the light period ( $14 \mathrm{~h}$, approximately $150 \mu \mathrm{mol}$ photons $\left.\mathrm{m}^{-2} \mathrm{~s}^{-1}\right)$. During the dark period $(10 \mathrm{~h})$, temperatures of $5^{\circ} \mathrm{C}$ (chamber wall temperature) and $20^{\circ} \mathrm{C}$ (water pan temperature) were used, respectively. Relative humidity inside the guttation chamber was $85 \%$ for the light period and $90 \%$ for the dark period. Chenopodium amaranticolor was grown inside a greenhouse and used as a local lesion host for BMV infectivity assays. Sources of BMV and production of an antibody against purified BMV virion were described previously (14).

Collection of guttation fluid and measurement of $\mathrm{pH}$ value. Guttation fluid was gently collected with a micropipet from the fourth and fifth leaves (the first and second leaves above the inoculated leaf) of each BMV-inoculated or mock-inoculated barley or wheat plant at various days postinoculation (dpi). Guttation fluid on leaves of maize cv. B73 plants was collected at 7 (fifth leaf) and $10 \mathrm{dpi}$ (sixth leaf). The fifth and sixth leaves represented the second and third leaves above the inoculated leaf. Guttation fluid on leaves of maize cv. V35 plants was collected at 10 (sixth leaf), 14 (sixth leaf), and 21 dpi (seventh leaf). The sixth and seventh leaves represented the third and fourth leaves above the inoculated leaf. The collected guttation fluid from each plant was immediately inoculated onto leaves of 4-week-old C. amaranticolor (10 to $15 \mu \mathrm{l}$ per leaf; two leaves per sample), and the inoculated plants were kept inside a greenhouse for 2 weeks. The number of lesions that developed in the leaves of $C$. amaranticolor was counted at $7 \mathrm{dpi}$. For each experiment, three virus-inoculated and three mock-inoculated plants were used, and the experiment was repeated three times.

To compare the $\mathrm{pH}$ value of the guttation fluid from infected barley with that from mock-inoculated barley, fluids collected from $15 \mathrm{BMV}$-inoculated or 15 mock-inoculated barley plants were pooled and measured immediately with a $\mathrm{pH}$ sensor as described by the manufacturer (pH-30; Corning Inc., Corning, NY). This experiment was repeated five times.

Time course study. Guttation fluid was collected at various dpi from the virus-inoculated or mock-inoculated 'Morex' plants as described previously and individually inoculated immediately onto leaves (10 $\mu \mathrm{l}$ per leaf) of $C$. amaranticolor or 'Morex'. BMV infectivity was determined by the number of lesions developed in the inoculated leaves at $7 \mathrm{dpi}$. This experiment was repeated four times. To determine the stability of BMV in guttation, fluid from leaves of 15 BMV-inoculated or 15 mock-inoculated 'Morex' plants were pooled, and an aliquot $(10 \mu \mathrm{l})$ was inoculated to a leaf of $C$. amaranticolor after $0,1,2,3,5$, and 7 days incubation at room temperature (RT). In two of the four experiments conducted, purified BMV or BMV RNA isolated from purified virion, as described previously (32), was added to the guttation fluid collected from the mock-inoculated barley to a concentration of $1 \mu \mathrm{g}$ of virus per milliliter of guttation fluid or $0.2 \mu \mathrm{g}$ of BMV RNA per microliter of guttation fluid. These samples were inoculated onto leaves ( $10 \mu \mathrm{l}$ per leaf and two leaves per sample) of $C$. amaranticolor as controls. Development of local lesions in the $C$. amaranticolor leaves was observed as described previously.
To determine if BMV in guttation fluid could infect barley cv. Morex through hydathodes on unwounded leaf surface, drops of guttation fluid ( $20 \mu \mathrm{l}$ per drop and 4 to 5 drops per leaf) containing purified BMV ( $2 \mu \mathrm{g}$ of virus per $\mu \mathrm{l})$ were placed on the surface of the leaves on 10-day-old plants. These plants were then grown inside a growth chamber under standard condition for approximately 3 weeks. BMV infection in these plants was analyzed at 20 dpi by symptom development and biological assay on leaves of C. amaranticolor.

Detection of BMV virion and coat protein in guttation fluid. Guttation fluid from BMV-infected or uninfected 'Morex' at 8 dpi was placed onto 200-mesh nickel grids precoated with Formvar and carbon. After 1 min staining with a $1 \%$ uranyl acetate solution, the grids were examined and photographed under an electron microscope (10A; Zeiss, Thornwood, NY) operating at $80 \mathrm{kV}$. To assay BMV capsid protein (CP) in guttation, fluid from five plants grown in the same pot were pooled and stored at $-80^{\circ} \mathrm{C}$. Three pots of BMV-inoculated and two pots of mock-inoculated plants were used in each experiment, and the experiment was repeated four times. Double-antibody sandwich, enzyme-linked immunosorbent assay (DAS-ELISA) was performed according to Barbara and Clark (3). Briefly, microtiter plates coated with the $F\left(a b^{\prime}\right) 2$ fragments $(1: 3,000$, vol/vol, in coating buffer) from the BMV antibody were incubated overnight with guttation samples at $4^{\circ} \mathrm{C}$. After washing, the plates were incubated with the BMV antibody solution $\left(1: 10,000\right.$, vol/vol, in ELISA buffer) for $3 \mathrm{~h}$ at $37^{\circ} \mathrm{C}$, washed, and incubated for $3 \mathrm{~h}$ at $37^{\circ} \mathrm{C}$ with a goat anti-rabbit immunoglobulin (Ig)G alkaline phosphatase conjugate solution (Promega, Madison, WI) (1:7,500, vol/vol, in ELISA buffer).

Immunocytochemistry. To localize BMV on the surface of the infected 'Morex' leaves, tissues $(20 \times 5 \mathrm{~mm})$ were randomly sampled from the fifth leaves on plants grown inside the guttation chamber at 10 to $12 \mathrm{dpi}$ and fixed for 2 to $3 \mathrm{~h}$ in $3.7 \%$ paraformaldehyde in $0.1 \mathrm{M}$ phosphate buffer, $\mathrm{pH} 7.0$, at RT. The fixed tissues were washed three times (10 min each) in the phosphate buffer and incubated for $3 \mathrm{~h}$ on drops of BMV antibody solution ( $1: 10,000, \mathrm{vol} / \mathrm{vol}$, in a $2 \%$ bovine serum albumin [BSA] solution) at RT. The tissues were then washed three times (10 min each) in the phosphate buffer followed by a 2 -h incubation in a goat antirabbit IgG flourescein isothiocyanate (FITC) conjugate (Sigma Chemical, St. Louis) (1:100, vol/vol, in a $2 \%$ BSA solution). After three washes in distilled water, the tissues were examined under a fluorescence microscope (Microphot-FX; Nikon, Melville, NY) for FITC labeling signal. A total of four infected and four uninfected tissues were analyzed in each of the two experiments conducted. For each tissue analyzed, three rows of 100 stomata were randomly chosen and examined for the labeling signal. Images of stomata containing the labeling signal were captured using the fluorescence microscope and a charge-coupled device (CCD) camera (Model C2400; Hamamatsu Photonics, Hamamatsu, Japan) connected to an image processor (Argus 20; Hamamatsu Photonics), and processed using Optimas 6.0 software (Optimas Co., Bothell, WA).

To detect BMV in cells of nonembedded 'Morex' leaves, tissues $(1 \times 0.5 \mathrm{~cm})$ were sampled from the fourth or fifth leaves of the infected and mock-inoculated plants grown inside the guttation chamber. After a $2 \mathrm{~h}$ fixation in the $3.7 \%$ paraformaldehyde solution and three washes in distilled water, paradermal sections (approximately $100 \mu \mathrm{m}$ thick) were cut with a Vibratome (Series 1000; Technical Products International, St. Louis). The sections (nonembedded) were transferred onto glass cover slides, covered with a thin film of $0.75 \%$ agar as described by Brown and Lemmon (7). The sections were then incubated in a $2 \%$ BSA solution for $30 \mathrm{~min}$ at RT followed by overnight incubation in the BMV antibody solution (1:10,000, vol/vol, in $2 \% \mathrm{BSA})$ at $4^{\circ} \mathrm{C}$. The sections were washed three times in the phosphate buffer, followed by a $2 \mathrm{~h}$ incubation in a goat anti-rabbit IgG FITC conjugate at RT. After three washes in distilled water, the sections 


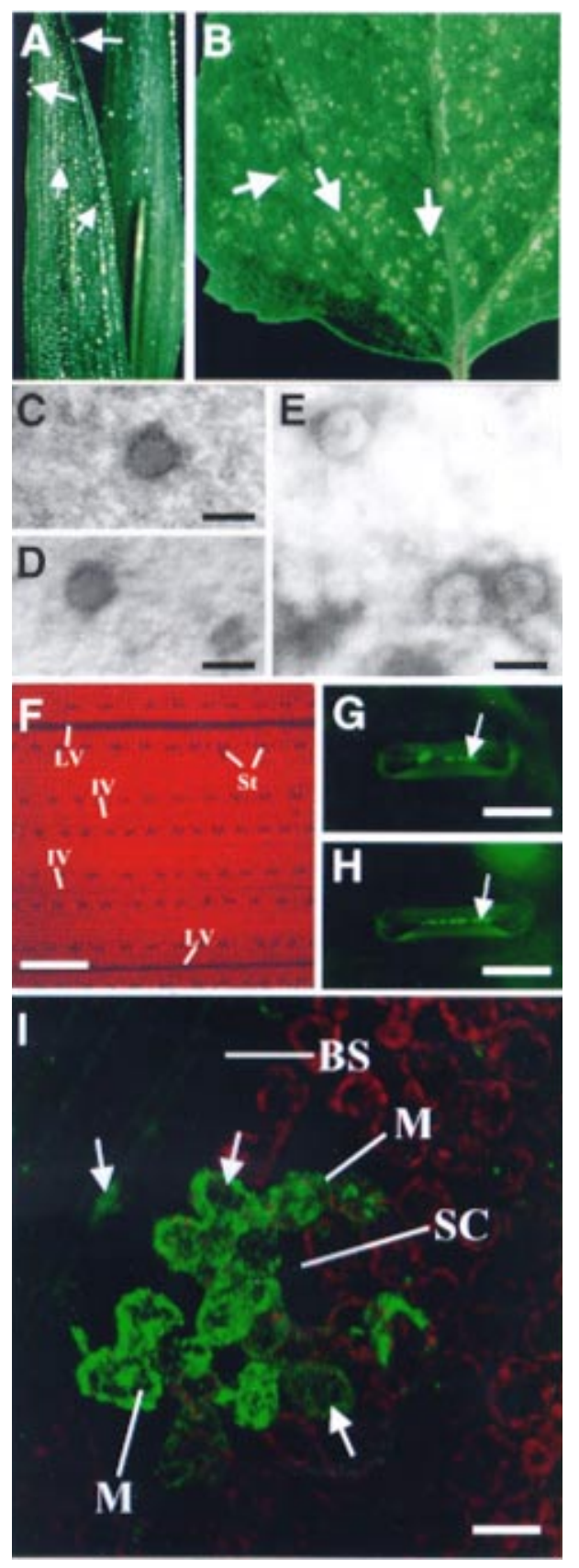

Fig. 1. Detection of Brome mosaic virus (BMV) in guttation fluid from virusinoculated barley cv. Morex. A, Guttation fluid on an infected 'Morex' plant grown inside the guttation chamber. Photograph was taken at $1 \mathrm{~h}$ before the light period began. Arrows indicate large guttation droplets on leaf edge. Arrowheads indicate small guttation droplets on surface and near veins. B, Local lesions (arrows) on a Chenopodium amaranticolor leaf inoculated with guttation fluid from an infected 'Morex' plant. Photograph was taken at 4 days postinoculation. $\mathbf{C}$ and $\mathbf{D}$, Virus-like particles observed in guttation samples from BMV-infected 'Morex' by electron microscopy. E, BMV particles observed in a crude extract from leaves of a BMV-infected 'Morex' plant by electron microscopy. Bar $=30 \mathrm{~nm}$. F, Confocal image of a barley leaf surface showing stomata (St) adjacent to large veins (LV) and intermediate longitudinal veins (IV). Bar $=0.3 \mathrm{~mm}$. G and $\mathbf{H}$, Stomata from two infected barley leaf blades probed with an antibody against BMV coat protein (CP) followed by a goat anti-rabbit immunoglobulin (Ig)G fluorescein isothiocyanate (FITC) conjugate. Green labeling signal (arrows) seen specifically at the pore of the stomata. Image of antibody-labeled stomata captured with a microscope and a charge-coupled device camera connected to an image processor. Bar $=28 \mu \mathrm{m}$. I, Section from a nonembedded, BMV-infected barley leaf blade and analyzed for BMV CP accumulation using an antibody against BMV followed by a goat anti-rabbit IgG FITC conjugate. The section was imaged by confocal microscopy. Arrows indicate cells showing labeling signal. BS, bundle sheath cell; M, mesophyll cell; and SC, substomatal chamber. Bar $=33 \mu \mathrm{m}$. were examined and imaged under a confocal system (Model 1024ES; Bio-Rad Laboratories, Hercules, CA) attached to an upright microscope (Axioskop, Zeiss, Thornwood, NY).

To determine the presence of BMV in intracellular spaces in infected 'Morex' leaves, tissues were randomly sampled from the fourth leaf of BMV-inoculated or mock-inoculated plants grown inside the growth chamber at $8 \mathrm{dpi}$, fixed, embedded in the LR White resin ${ }^{\circledR}$, sectioned, and probed with the BMV antibody followed by immunogold conjugates as described previously (14). For light microscopy, the immunogold labeling signal was silver enhanced for $8 \mathrm{~min}$ and Nomarski images of the sections were captured with the fluorescence microscope and CCD camera. For electron microscopy, the sections were prepared and stained with uranyl acetate and Reynold's lead citrate, and viewed under an electron microscope as described previously (13).

Assay of $\mathrm{H}_{2} \mathrm{O}_{2}$ and cell death in BMV-infected 'Morex' and 'V35' leaves. Presence of $\mathrm{H}_{2} \mathrm{O}_{2}$ was assayed by the 3,3'-diaminobenzidine (DAB)-uptake method described previously (51), with specific modifications. Tissues $(10 \times 0.5 \mathrm{~cm})$ were cut from the fifth leaf of the BMV-inoculated or mock-inoculated 'Morex' plants at $8 \mathrm{dpi}$ and the sixth and seventh leaves of the BMV-inoculated or mock-inoculated 'V35' plants at 12 and 21 dpi. They were incubated in a DAB solution, $\mathrm{pH} 3.8$, for $4 \mathrm{~h}$ at RT followed by a $4 \mathrm{~h}$ incubation in a $95 \%$ ethanol solution at $80^{\circ} \mathrm{C}$ and placed overnight in a fresh $95 \%$ ethanol solution at RT. After $15 \mathrm{~min}$ in $50 \%$ ethanol, the tissues were transferred to a $75 \%$ glycerol solution. Bright field images of the tissues were captured with the transmission detector of the confocal system. Localized cell death in infected 'Morex' or 'V35' leaves was analyzed by the trypan blue staining as previously described (5). Briefly, tissues were collected from the systemically infected or uninfected leaves as described for the $\mathrm{H}_{2} \mathrm{O}_{2}$ assay, placed in a $70^{\circ} \mathrm{C}$ trypan blue solution, vacuum-infiltrated for $1 \mathrm{~min}$, and heated over boiling water for $2 \mathrm{~min}$. After a further $30 \mathrm{~min}$ incubation in the same solution at RT, the tissues were destained in a chloral hydrate solution (three times, $60 \mathrm{~min}$ each time) and overnight at RT. The tissues were transferred into a $70 \%$ glycerol solution, examined, and photographed with a Nikon camera connected to the fluorescence microscope as bright field images.

6(5)-Carboxyfluorescein diacetate and 3-kDa Texas red dextran staining. 6(5)-Carboxyfluorescein diacetate (CFDA) and 3-kDa Texas red dextran (Molecular Probes, Eugene, OR) were used, respectively, to investigate phloem and xylem transport in intact plants $(9,20,30,43,48)$. To observe phloem and xylem transport in infected and uninfected barley cv. Morex and maize cv. V35 leaves, plants were inoculated with BMV or phosphate buffer as described previously. The inoculated plants were grown inside the guttation chamber. At 10 (cv. Morex) or 12 and $21 \mathrm{dpi}(\mathrm{cv}$. V35), the fifth leaf (cv. Morex) or the sixth and seventh leaves (cv. V35) of each BMV-inoculated or mock-inoculated plant was dusted with Carborundum and a small surface area of each leaf was abraded gently with a cotton swab. A drop of CFDA solution was applied to the abraded area $(5 \mu \mathrm{l}$ per area), and the treated areas were covered immediately with Saran Wrap (48). Thirty minutes after the CFDA application, the leaves were detached from the plants, and the sheath base of each leaf was immediately immersed in the Texas red dextran solution inside an Eppendorf tube (30 $\mu \mathrm{l}$ per tube, one leaf per tube). At 15 to $25 \mathrm{~min}$ after the Texas red dextran application, the leaves were examined and imaged by confocal microscopy.

\section{RESULTS}

Virus symptoms and formation of guttation on leaves. BMVinoculated barley (cvs. Morex, Callao, and Tam Bar 401) showed chlorotic streaks on systemic leaves by 5 dpi under the guttation chamber condition. Chlorotic streaks were observed on systemic leaves of BMV-inoculated wheat cv. Bounty 203 A and maize cv. 
V35 at 7 dpi. Symptoms on BMV-inoculated barley grown inside the guttation chamber were similar to those observed on BMVinoculated barley grown under the standard growth chamber condition described previously (14). BMV-inoculated maize cv. B73 showed the first signs of systemic necrosis by $6 \mathrm{dpi}$. The systemic necrosis progressed on these plants, and the infected plants died at approximately 12 dpi. No virus symptoms were observed on leaves of mock-inoculated barley, wheat, and maize plants under the guttation or standard growth chamber conditions.

Guttation was initially observed at the tip of barley, wheat, and maize leaves grown inside the guttation chamber approximately $4 \mathrm{~h}$ after the dark period began. The amount of guttation fluid on the leaf surface continued to increase and appeared on the edge and then on surface areas next to large and intermediate veins (Fig. 1A, Cucurbita pepo and Vigna unguiculata grown inside the same guttation chamber showed the classic pattern of guttation droplets at the leaf margin; data not shown). Guttation normally disappeared in approximately $5 \mathrm{~h}$ under the light period conditions. Approximately $15 \mu \mathrm{l}$ of guttation fluid was collected from a barley or a wheat plant per day, and $30 \mu \mathrm{l}$ of guttation fluid from a maize plant each day. The guttation fluid from BMV-infected barley plants had a consistently higher $\mathrm{pH}$ value than those from mock-inoculated barley plants in five different experiments $(6.2 \pm$ 0.13 for infected plants and $5.9 \pm 0.22$ for uninfected plants; $P<$ 0.05 by paired $t$ test analysis).

Infectivity of guttation fluid from infected plants. Guttation fluid from systemic leaves of BMV-inoculated or mock-inoculated barley (cvs. Morex, Callao, and Tam Bar 401) at 10 dpi were inoculated individually to leaves of the local lesion host, $C$. amaranticolor. All guttation samples from the BMV-inoculated 'Morex' plants induced lesions in the inoculated leaves of C. amaranticolor (Fig. 1B). For BMV-inoculated barley cvs. Callao and Tam Bar 401, 78\% of the guttation fluid from 'Callao' (seven of nine samples) and $89 \%$ of the guttation fluid from 'Tam Bar 401' (eight of nine samples) caused lesions in leaves of $C$. amaranticolor. In these experiments, the number of lesions induced in the leaves of $C$. amaranticolor by different samples varied greatly (ranging from 2 to 150 lesions per leaf), suggesting a wide variation of BMV concentrations within different samples (data not shown). All 'Morex' plants inoculated with a small amount of guttation fluid (10 $\mu \mathrm{l}$ per plant) from leaves of plants inoculated 10 days previously with BMV developed typical symptoms on newly developed leaves by $7 \mathrm{dpi}$, demonstrating the high infectivity of these guttation samples. For BMV-inoculated wheat cv. Bounty 203A, 67\% of the samples tested (six of nine samples) induced lesions in the leaves of $C$. amaranticolor. Interestingly, for BMV-inoculated maize cv. V35, a large amount of viral CP was detected in systemic leaves by western blot analysis (data not shown), but the guttation samples from these leaves at 10 (nine samples), 14 (nine samples), and 21 dpi (nine samples) did not induce lesions in the leaves of $C$. amaranticolor. Guttation samples from maize cv. B73 plants showing systemic necrosis at 7 (five samples) and 10 dpi (five samples), respectively, did not induce lesions in leaves of $C$. amaranticolor. In all experiments, the guttation fluid from the mock-inoculated plants did not induce

TABLE 1. Presence of Brome mosaic virus (BMV) in guttation fluid by collected from barley cv. Morex leaves at various days postinoculation (dpi)

\begin{tabular}{lcccc}
\hline & \multicolumn{4}{c}{ Time of guttation collection } \\
\cline { 2 - 5 } Guttation source & $5 \mathrm{dpi}$ & $7 \mathrm{dpi}$ & $9 \mathrm{dpi}$ & $11 \mathrm{dpi}$ \\
\hline BMV-inoculated plants & $6 / 12^{\mathrm{a}}$ & $10 / 12$ & $10 / 11$ & $10 / 10$ \\
Mock-inoculated plants & $0 / 12$ & $0 / 12$ & $0 / 12$ & $0 / 12$ \\
\hline
\end{tabular}

${ }^{a}$ Number of guttation samples that induced local lesions in Chenopodium amaranticolor leaves/number of guttation samples tested. Three BMVinoculated and three mock-inoculated plants were used in each of the four experiments conducted. Approximately $15 \mu \mathrm{l}$ of guttation fluid was collected each time from a plant. lesions in the leaves of $C$. amaranticolor. Thus, BMV was present in guttation fluid from the BMV-infected barley and wheat, but not maize, irrespective of symptom phenotype. We also determined that application of guttation fluid containing BMV onto barley leaves without mechanical wounding could not cause an infection in these plants by $21 \mathrm{dpi}$, based on viral symptoms and infectivity assays of extracts on C. amaranticolor (data not shown).

To determine if BMV existed in guttation fluid from BMVinoculated 'Morex' plants showing initial systemic symptoms, we analyzed guttation samples collected at various dpi. In these studies, BMV was present in $50 \%$ of the samples collected at $5 \mathrm{dpi}$ and the percentage increased at later sampling dates (Table 1). In a separate experiment, we analyzed guttation samples from five BMV-inoculated 'Morex' plants before (4 dpi) and after (5 and 7 dpi) the initial systemic symptoms were observed on them. Virus was present in samples collected at 5 and $7 \mathrm{dpi}$, but not in samples collected at 4 dpi (data not shown). These findings indicate a correlation between the accumulation of the virus in guttation fluid and the development of the initial symptoms on the systemic barley leaves.

Previous studies indicated that infectivity of BMV in crude leaf extracts lasted more than 20 days $(8,53)$. To determine the stability of BMV in guttation fluid, guttation samples from BMVinoculated and mock-inoculated 'Morex' were inoculated to leaves of $C$. amaranticolor after various days incubation at RT. Virus in guttation fluid was much less stable compared with that of purified BMV added to the guttation fluid from the mock-inoculated plants (Table 2). However, it was more stable than BMV RNA added to the guttation fluid from the mock-inoculated plants (Table 2). No BMV infectivity was detected in guttation fluid from the mock-inoculated plants (data not shown). These observations indicated that the viral genome in guttation fluid from the infected plants was partially protected from degradation, possibly by the CP.

Virion and BMV CP in guttation fluid. Under the electron microscope, virion-like particles were observed in guttation samples collected from the infected 'Morex' leaves (Fig. 1C and D). These particles had similar shapes and diameters to BMV virions seen in crude extracts prepared from BMV-infected 'Morex' leaves (Fig. 1E), and were not seen in guttation samples from uninfected plants (data not shown).

Results of biological assays indicated that the concentration of BMV in different guttation samples varied significantly. To further quantitate BMV in guttation fluid from barley, 20 samples from four different experiments were analyzed by ELISA. All samples from the infected plants contained the virus and the concentration of BMV CP in these samples ranged from approximately $1 \mathrm{ng} / 10 \mu \mathrm{l}$ to $50 \mathrm{ng} / 10 \mu \mathrm{l}$ of guttation fluid (Fig. 2). No BMV CP was detected in guttation fluid from the mock-inoculated plants by ELISA (data not shown).

Immunolocalization of BMV on the surface and in cells of cv. Morex leaves. To locate the sites where BMV was secreted

TABLE 2. Stability of Brome mosaic virus (BMV) in guttation fluid from infected and purified BMV or BMV RNA added to guttation fluid from uninoculated cv. Morex plants ${ }^{\mathrm{a}}$

\begin{tabular}{lccc}
\hline & \multicolumn{3}{c}{ Guttation from } \\
\cline { 2 - 4 } Experiment & $\begin{array}{c}\text { Infected } \\
\text { plants }\end{array}$ & $\begin{array}{c}\text { Uninoculated } \\
\text { plants + BMV }\end{array}$ & $\begin{array}{c}\text { Uninoculated } \\
\text { plants + BMV RNA }\end{array}$ \\
\hline I & 4 days & - & - \\
II & 2 days & - & - \\
III & 3 days & $>7$ days & $<3 \mathrm{~h}$ \\
IV & 3 days & $>7$ days & $<3 \mathrm{~h}$ \\
\hline
\end{tabular}

a Stability of virus or viral RNA was determined based on the induction of local lesions in the inoculated leaves of Chenopodium amaranticolor by 7 days postinoculation. -, not assayed. Guttation fluid from mock-inoculated cv. Morex did not cause lesions in the inoculated leaves of $C$. amaranticolor. 
onto the surface of systemically infected barley leaves, the surface of fixed tissues were probed with the antibody against BMV CP followed by the FITC conjugate. Figure $1 \mathrm{~F}$ shows stomata on the surface of a barley leaf. Green fluorescent signal from the FITC conjugate was observed specifically at the pore of stomata located adjacent to vascular bundles (Fig. $1 \mathrm{G}$ and $\mathrm{H}$ ). The percentages of labeled stomata in two experiments were 2.5 and $0.7 \%$ (Table 3). The surface of epidermal cells on the infected leaf tissues was not labeled with the antibody. The labeling signal was not seen using tissues from the mock-inoculated 'Morex' plants (Table 3; data not shown).

To localize BMV in different cell types in systemically infected 'Morex' leaves, nonembedded tissue sections were probed with the BMV antibody followed by the FITC conjugate. The fluorescent labeling signal was observed not only in vein cells but also in mesophyll cells adjacent to the bundle sheath cells. In most cases, these labeled mesophyll cells were located adjacent to substomatal chambers (Fig. 1I). When resin-embedded tissue sections were analyzed with the BMV antibody followed by an immunogold conjugate and silver enhancement, brown to black color labeling signal was observed in different types of vein cells and in intercellular spaces between the bundle sheath cells (Fig. 3A). Immunocytochemistry and electron microscopy using thin sections from the same tissue shown in Figure 3A provided similar results (Fig. $3 \mathrm{~A}$, insert). No immunogold labeling signal was seen in guard cells or within substomatal chambers by both light and electron microscopy (data not shown). No labeling signal was observed on

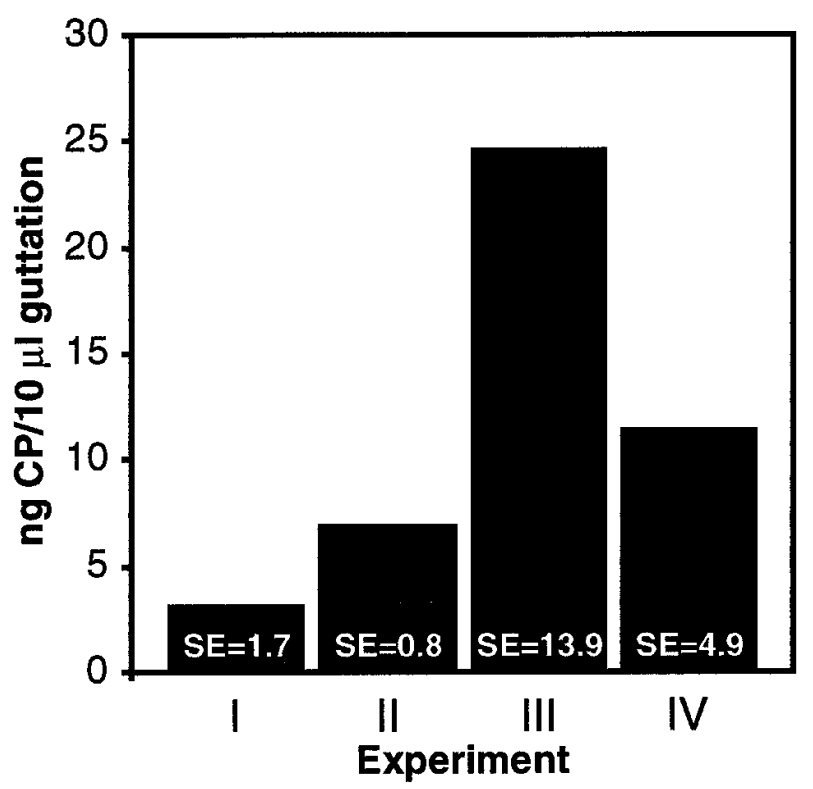

Fig. 2. Presence of Brome mosaic virus (BMV) coat protein (CP) in guttation fluid determined by enzyme-linked immunosorbent assay. Guttation fluid was collected from infected barley at approximately 10 days postinoculation. In each of the four experiments conducted, three samples from BMV-inoculated and two samples from mock-inoculated plants were analyzed. No BMV CP was detected in guttation fluid from mock-inoculated plants (data not shown). SE, standard error.

TABLE 3. Immunodetection of Brome mosaic virus (BMV) coat protein (CP) at the stomatal pores on BMV-inoculated or mock-inoculated cv. Morex leaves

\begin{tabular}{lcc}
\hline Experiment & BMV-inoculated & Mock-inoculated \\
\hline I & $30 / 1,200^{\mathrm{a}}$ & $0 / 1,200$ \\
II & $9 / 1,200$ & $0 / 1,200$
\end{tabular}

a Number of stomata containing BMV CP/number of stomata examined. Four leaf tissues were used in each of the two experiments. For each tissue, three rows of 100 stomata were examined for the fluorescent labeling signal. the surface of uninfected leaf tissues or in cells in sections from mock-inoculated plants (Fig. 3B; data not shown).

$\mathrm{H}_{2} \mathrm{O}_{2}$ assay, trypan blue, and fluorescent dye staining. It is generally accepted that BMV induces chlorotic streaks and not necrotic lesions in infected barley leaves $(32,37,39)$. To investigate the potential sites where BMV exits the infected vein cells and accumulates in intercellular spaces, we analyzed tissues from systemically infected 'Morex' and 'V35' leaves for $\mathrm{H}_{2} \mathrm{O}_{2}$ accumulation by the DAB-uptake method and cell death by the trypan blue staining method. The DAB-uptake experiments showed that $\mathrm{H}_{2} \mathrm{O}_{2}$, which triggers hypersensitive death of pathogen-challenged plant cells (33), had accumulated in vascular cells and in mesophyll cells adjacent to vascular bundles in infected 'Morex' leaves

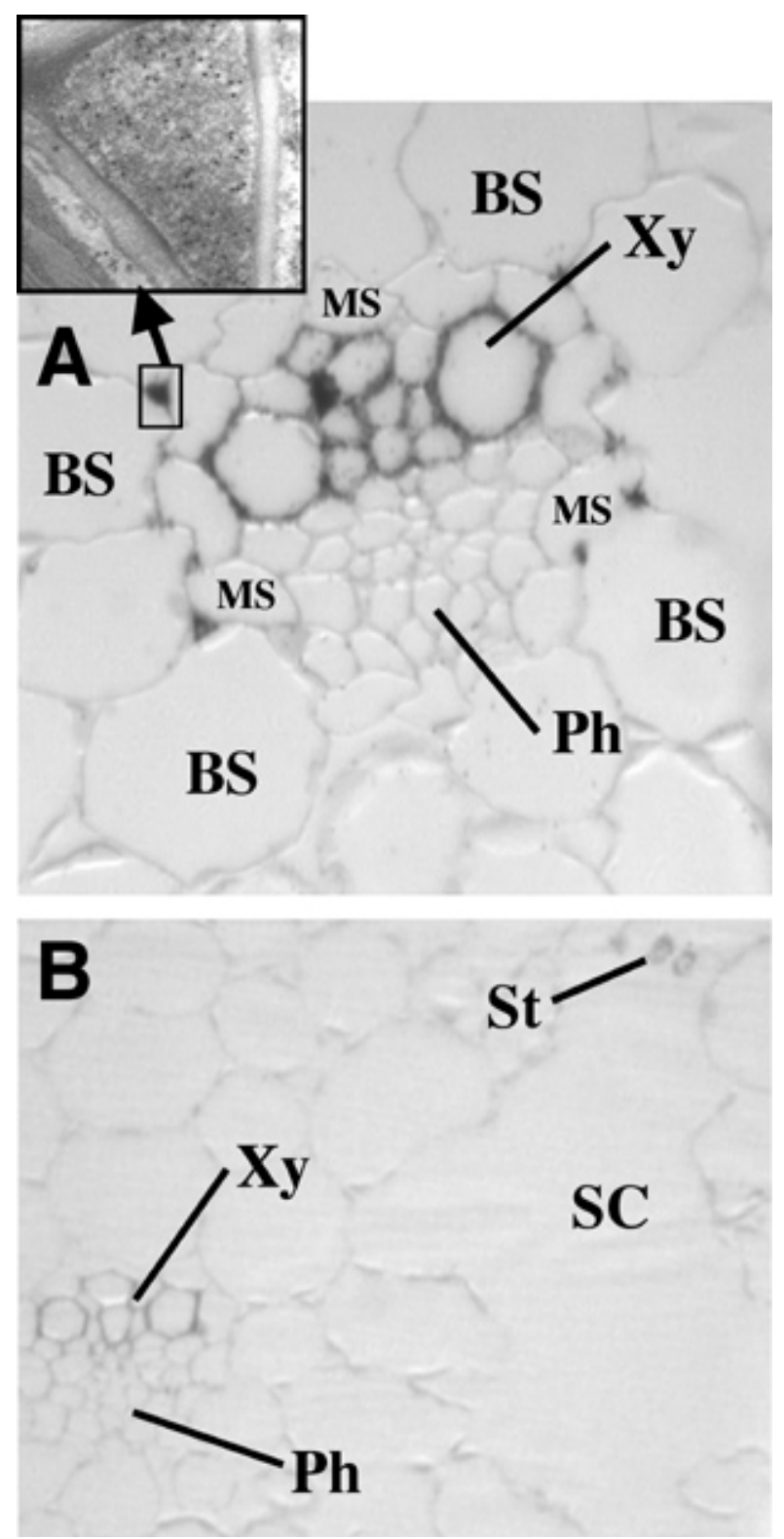

Fig. 3. Accumulation of Brome mosaic virus (BMV) in cells of a systemically infected barley leaf blade at 8 days postinoculation. Accumulation of BMV was analyzed by immunocytochemistry using an antibody against BMV coat protein followed by a goat anti-rabbit immunoglobulin $\mathrm{G}$ gold conjugate $(5 \mathrm{~nm})$ and silver enhancement. Nomarski images were captured with equipment described in Figure $1 \mathrm{G}$ and H. A, Section from an infected barley leaf. Arrow points to an electron microscopy image of the boxed area. Immunogold particles $(20 \mathrm{~nm})$ can be seen in the intercellular space. Bar $=16 \mu \mathrm{m}$. B, Section from an uninfected barley leaf and treated similar to sections from BMVinfected barley leaves. BS, bundle sheath cell; MS, mestome sheath cell; $\mathrm{Ph}$, phloem; SC, substomatal chamber; St, stomata; and Xy, xylem. Bar $=35 \mu \mathrm{m}$. 
(Fig. 4A and B). Accumulation of $\mathrm{H}_{2} \mathrm{O}_{2}$ was not detected in cells of uninfected 'Morex' leaves (Fig. 4C) $\mathrm{H}_{2} \mathrm{O}_{2}$ accumulation was not detected in cells of infected or uninfected 'V35' leaves (Fig. 4D and E). Results of trypan blue staining demonstrated patches of dead cells in and adjacent to vasculature in infected 'Morex' leaves (Fig. 5A). These dead cells were not distinguishable before the trypan blue staining (data not shown). No such dead cells were identified in infected 'V35' leaves (Fig. 5C) or in tissues from the uninfected 'Morex' and 'V35' leaves (Fig. 5B and D).

Because dead cells were observed in and adjacent to vasculature in the infected 'Morex' leaves, we decided to investigate the phloem and xylem transport in infected 'Morex' and 'V35' leaves with two fluorescence dyes. CFDA was applied to 'Morex' and 'V35' leaves through abraded areas, and 3-kDa Texas red dextran was applied through a cut in the sheath tissue. In infected 'Morex' leaves, the Texas red dextran spreads quickly along the xylem tracheary and, in some areas, diffused from the tracheary elements into areas between two longitudinal veins (Fig. 5E). CFDA spreads in the phloem network. It was also observed in some interveinal areas in the infected 'Morex' leaves. However, in comparison with Texas red dextran, the number of interveinal areas containing CFDA were fewer (Fig. 5F). In infected 'V35' and uninfected 'Morex' and 'V35' leaves, both dyes spread only within vascular bundles (Fig. 5G to J; data not shown). These observations suggest strongly that BMV infection caused severe damage to vasculature, particularly the xylem treachery, in infected barley leaves.

\section{DISCUSSION}

Guttation is a common reaction of many plant species when conditions favor water uptake through roots but limit transpiration through leaves $(21,52)$. Early studies demonstrated that guttation fluid from plant leaves contain significant amounts of inorganic and organic substances $(10,41,54)$. Further studies from other groups showed that different types of peroxidases exist in guttation fluid from leaves of different plant species, including some grasses $(4,28,36)$. Interestingly, several plant viruses were also found in guttation fluid from their hosts $(16,17,25 ;$ X. S. Ding and R. S. Nelson, unpublished data). Because BMV was detected in the guttation fluid from most infected cvs. Morex, Callao, and Tam Bar 401 plants analyzed, we conclude that the presence of the virus in guttation fluid from infected barley is common. Considering that plant viruses are most often associated with the plant symplasm (40), an important question arises as to how and where the virus exits infected cells, accumulates in intercellular spaces, and reaches the surface of infected leaves.

We previously determined that BMV was able to reach uninoculated young 'Morex' leaves by 2.5 dpi via phloem-dependent movement (14). Also, the virus accumulated predominantly in vein cells and in mesophyll cells adjacent to vascular bundles in both inoculated and systemically infected barley leaves under the $24 / 20^{\circ} \mathrm{C}$ (day/night) conditions. In this study, we observed the virus in some mesophyll cells adjacent to substomatal chambers (large air spaces beneath the stomata) near vascular bundles (Fig. 1I) and in intercellular spaces between mestome and bundle sheath cells by both light and electron microscopy (Fig. 3A and B). BMV may exit from the infected cells by two routes. First, the virus may exit infected cells through plasmodesmata in their walls as suggested by Paliwal (44). However, plasmodesmatal trafficking is considered symplastic and therefore cannot explain the appearance of the virus in intercellular space $(35,40)$. Secondly, the virus may enter intercellular spaces through damaged walls of the infected cells. Results from our work show that hydrogen peroxide, which is involved in hypersensitive reaction (33), was detected in cells within and adjacent to vascular bundles in BMV-infected 'Morex' leaves (Fig. 4A and B). We have also detected small patches of dead cells localized within and adjacent
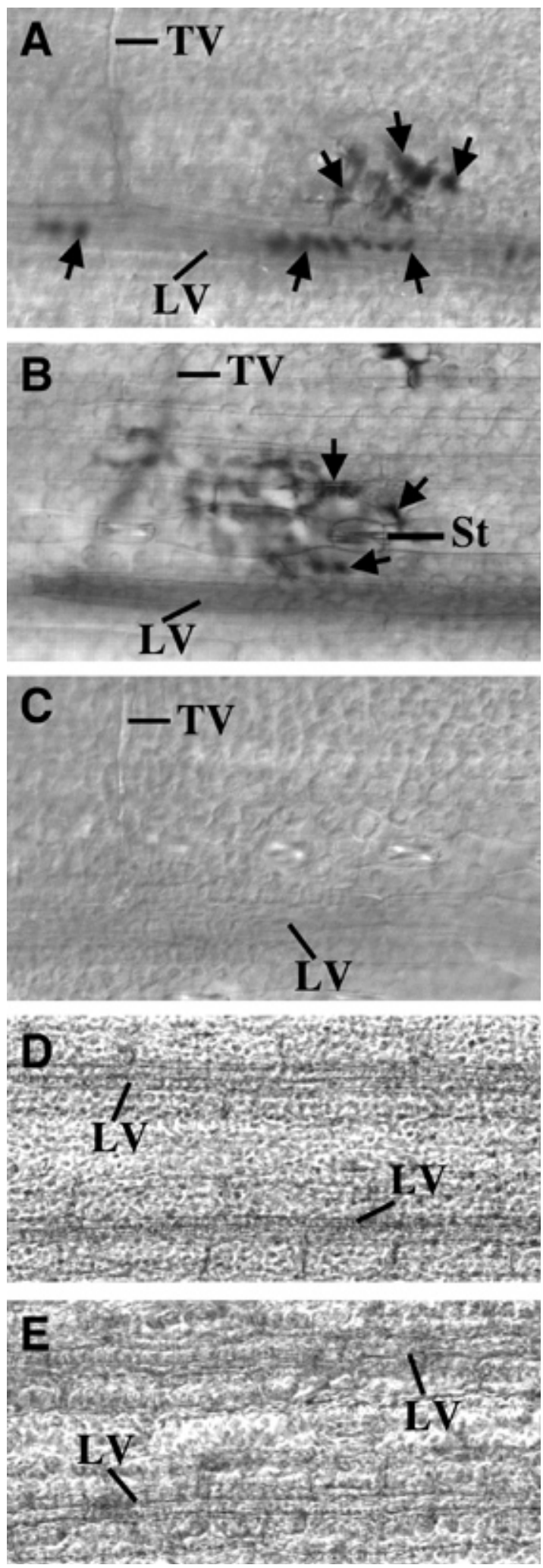

Fig. 4. Detection of $\mathrm{H}_{2} \mathrm{O}_{2}$ accumulation in cells of leaf blades from Brome mosaic virus (BMV)-infected barley cv. Morex and maize cv. V35. A and B, Tissues were from BMV-infected 'Morex' plants and treated with a 3,3'-diaminobenzidine (DAB) solution. Accumulation of $\mathrm{H}_{2} \mathrm{O}_{2}$ in cells is shown by the dark color staining (arrows). Images of the tissues were captured by the transmission detector of the confocal microscope system. Bar $=54 \mu \mathrm{m}$. C, Tissue was from a mock-inoculated 'Morex' plant and treated similar to tissues from infected plant. The DAB staining was not observed in cells of this tissue. Bar $=54 \mu \mathrm{m}$. D and E, Tissues were from 'V35' plants inoculated with D, BMV or E, phosphate buffer. No DAB staining was observed in cells of these tissues. LV, longitudinal vein; St, stoma; and TV, transverse vein. Bar $=80 \mu \mathrm{m}$. 
to veins in the infected 'Morex' leaves by trypan blue staining (Fig. 5A). Under the microscope, some dead cells or cells that accumulated $\mathrm{H}_{2} \mathrm{O}_{2}$ were seen under the stomata (Fig. 4B; data not shown). Furthermore, we determined with xylem- and phloemspecific dyes that the xylem network, and to a much lesser extent the phloem network, in BMV-infected 'Morex' leaves were porous (Fig. 5E and F). Taken together, we propose that BMV exits infected xylem tracheary and, in some cases, phloem cells through their damaged walls, accumulates in the intercellular spaces, and then reaches the surface through stomatal pores during the process of guttation or transpiration. Because barley leaves contain numerous stomata on their surface (Fig. 1F; data not shown), large amounts of BMV may accumulate on the surface of a leaf through a small percentage of stomata associated with damaged vascular bundles.
One way to determine the relationship between the localized cell death in infected leaves and the accumulation of BMV in guttation is to identify hosts that do not show localized cell death or show systemic necrosis after BMV infection and then determine the presence of the virus in guttation fluid. Like many maize cultivars reported previously $(15,37,53)$, maize $\mathrm{cv}$. B73 showed a systemic necrosis to BMV infection. Virus, however, was not detected in guttation fluid from these plants. It is possible that systemic necrosis prevents release of BMV into and transport through the xylem, consequently restricting BMV accumulation in guttation on infected leaves. In contrast to results with maize cv. B73 plants, maize cv. V35 plants developed only chlorotic streaks on the systemically infected leaves. Analysis of tissues from the infected 'V35' leaves by the DAB-uptake method (Fig. 4D) and trypan blue staining (Fig. 5C) did not reveal a localized cell death
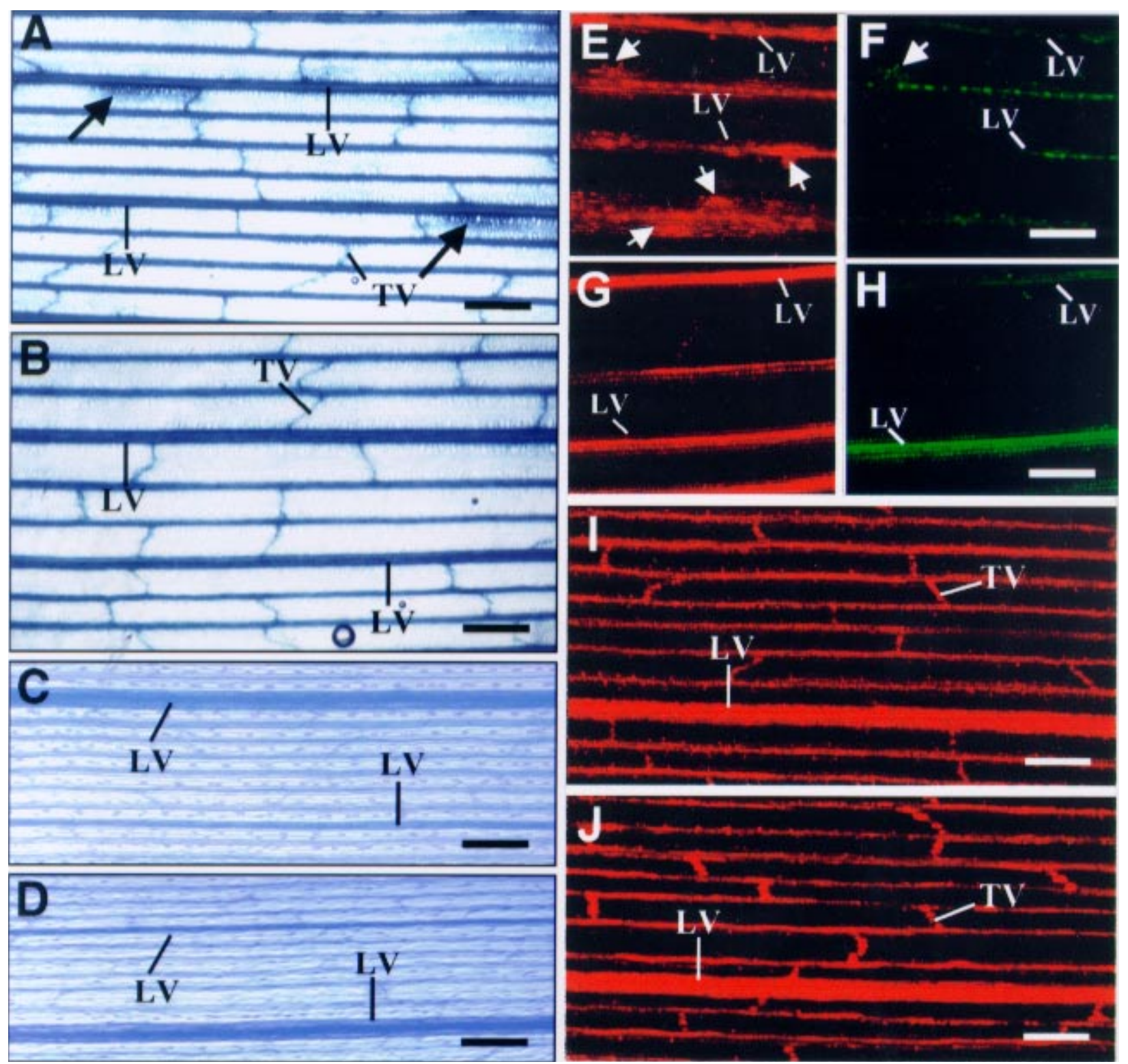

Fig. 5. Analysis of localized cell death and dye transport in xylem and phloem network in leaves of Brome mosaic virus (BMV)-infected barley cv. Morex and maize cv. V35 plants. A and B, Tissues were from leaf blades of 'Morex' plants inoculated with A, BMV or B, phosphate buffer at 10 days postinoculation (dpi). They were stained with a trypan blue solution and photographed under the fluorescence microscope as bright field images. Arrows indicate patches of dead cells adjacent to veins. Bar $=0.6 \mathrm{~mm}$. C and D, Tissues were from leaf blades of 'V35' inoculated with C, BMV or D, phosphate buffer at 21 dpi. No dead cells were observed in these tissues. Bar $=0.6 \mathrm{~mm}$. E and F, A leaf blade from a BMV-infected 'Morex' at 10 dpi. E, Transport in xylem and $\mathbf{F}$, phloem network was visualized by the 3-kDa Texas red dextran and 6(5)-carboxyfluorescein diacetate (CFDA), respectively. Fluorescent signal from Texas red dextran, and occasionally from CFDA, was observed in interveinal areas (arrows) of the tissue. Images of the dye transport were captured with a confocal microscope system. Bar $=0.28 \mathrm{~mm}$. G and $\mathbf{H}$, A leaf blade from a mock-inoculated 'Morex' and analyzed for the $\mathbf{G}$, xylem and $\mathbf{H}$, phloem transport as done for $\mathbf{E}$ and $\mathbf{F}$. Bar $=0.28 \mathrm{~mm}$. I and J, Leaf blades from 'V35' plants inoculated with I, BMV or J, phosphate buffer, respectively, at 21 dpi. The blades were analyzed for xylem transport as described for 'Morex' leaves. LV, longitudinal vein; and TV, transverse vein. Bar $=0.3 \mathrm{~mm}$. 
response as described previously for the BMV-infected 'Morex' leaves (Figs. 4A and $\mathrm{B}$ and $5 \mathrm{~A}$ ). Although BMV CP can be readily detected in infected ' $\mathrm{V} 35$ ' leaves by serological assay (data not shown), guttation fluid from these leaves (between 10 to $21 \mathrm{dpi}$ ) did not contain the virus as determined by biological assay. Thus, a localized cell death response in a susceptible host, not associated with systemic necrosis, may be necessary for BMV to move systemically through vascular bundles, exit damaged xylem cells, and accumulate intercellularly in the infected leaves.

Typical BMV symptoms in barley and wheat are chlorotic streaks on leaves and stunting of plants. To our knowledge, there is no previous report indicating a cell death response in barley or wheat after BMV infection. Therefore, viral and host factors involved in the cell death response in these plants are unknown. Because the virus was detected in the guttation fluid from infected barley by $5 \mathrm{dpi}$, a time when initial systemic symptoms were observed on young barley leaves (Table 1), the process of cell death must start early after the virus invasion of this tissue, or perhaps even before the virus is transported to the site from the lower inoculated leaves. Studies are being directed at determining where and when the initial cell death starts in systemically infected barley leaves.

Previous reports indicate that infectivity of BMV in crude leaf extracts lasts more than 20 days under room temperature conditions $(8,53)$. We determined that BMV infectivity in guttation fluid from infected leaves was not maintained as long as that of purified BMV added to the guttation fluid from the mock-inoculated barley leaves (Table 2). Destabilization of BMV in guttation fluid from infected barley might be due to factors released from the host or to an increase of the $\mathrm{pH}$ value of the guttation fluid from the infected plants. Evidence exists that BMV is unstable when the $\mathrm{pH}$ value of the solution is above 6.5 (32).

Although BMV can be mechanically transmitted or vectored by beetles or nemotodes in the laboratory, its mode of transmission in nature is unknown. We have determined that, under the controlled conditions, BMV was able to exit from infected vein cells, accumulate in intercellular spaces, and reach the surface of barley leaves through the process of guttation (Figs. 1 to 3; Table 1). Because guttation fluid from BMV-infected plants was infectious for extended periods of time (Table 2), it is possible that infectious virus could be carried to adjacent plants in a field by vertebrate or invertebrate vectors and cause further infection in field. McKinney (38) demonstrated that humans walking in pastures resulted in BMV spread among smooth brome grass and orchard grass.

Taken together, our work provides evidence that BMV infection in barley causes a localized cell death that then allows the virus to escape from infected cells to the intercellular space. Once in the intercellular space, the virus may be carried by the transpiration stream or by guttation to the leaf surface. Because guttation accumulates on the leaf surface, it becomes readily accessible to various vectors that may come in contact with the leaf, thereby potentially facilitating BMV spread in the field.

\section{ACKNOWLEDGMENTS}

We thank L. C. Lane for supplying maize seed; S. Russell and G. Strout for access to the electron microscope facility at the University of Oklahoma; E. Blancaflor, G. May, and M. N. A. Yassi for their critical comments during preparation of the manuscript; K. Spiering for maintaining growth chambers; C. Ly for preparing figures; and A. Wilkins for typing the manuscript.

\section{LITERATURE CITED}

1. Ahlquist, P. 1999. Bromoviruses (Bromoviridae). Pages 198-204 in: Encyclopedia of Virology. A. Granoff and R. G. Webster, eds. Academic Press, San Diego.
2. Ahlquist, P., Luckow, P., and Kaesberg, P. 1981. Complete nucleotide sequence of brome mosaic virus RNA3. J. Mol. Biol. 153:23-38.

3. Barbara, D. J., and Clark, M. F. 1982. A simple indirect ELISA using $\mathrm{F}\left(\mathrm{ab}^{\prime}\right) 2$ fragments of immunoglobulin. J. Gen. Virol. 58:315-322.

4. Biles, C. L., and Abeles, F. B. 1991. Xylem sap proteins. Plant Physiol. 96:597-601.

5. Bowling, S. A., Clarke, J. D., Liu, Y., Klessig, D. F., and Dong, X. 1997. The cpr5 mutant of Arabidopsis expresses both NPR1-dependent and NPR1-independent resistance. Plant Cell 9:1573-1584.

6. Boyer, J. S. 1985. Water transport. Annu. Rev. Plant Physiol. 36:473-516.

7. Brown, R. C., and Lemmon, B. E. 1995. Methods in plant immunolight microscopy. Pages 85-107 in: Methods in Plant Cell Biology. D. W. Galbraith, H. J. Bohnert, and D. P. Bourque, eds. Academic Press, San Diego.

8. Büchen-Osmond, C. 1996. Brome mosaic bromovirus. Pages 267-270 in: Viruses of Plants: Descriptions and Lists from the VIDE Database. A. Brunt, K. Crabtree, M. Dallwitz, A. Gibbs, and L. Watson, eds. CAB International, Oxon, U.K.

9. Cheng, N.-H., Su, C.-L., Carter, S. A., and Nelson, R. S. 2000. Vascular invasion routes and systemic accumulation patterns of tobacco mosaic virus in Nicotiana benthamiana. Plant J. 23:349-362.

10. Curtis, L. C. 1944. The exudation of glutamine from lawn grass. Plant Physiol. 19:1-5.

11. Dasgupta, R., and Kaesberg, P. 1982. Complete nucleotide sequences of the coat protein messenger RNAs of brome mosaic virus and cowpea chlorotic mottle virus. Nucleic Acids Res. 10:703-713.

12. Demski, J., and Chalkley, J. 1979. Non-movement of cowpea chlorotic mottle virus from cowpea and soybean. Plant Dis. Rep. 63:761-764.

13. Ding, X. S., Carter, S. A., Deom, C. M., and Nelson, R. S. 1998. Tobamovirus and potyvirus accumulation in minor veins of inoculated leaves from representatives of the Solanaceae and Fabaceae. Plant Physiol. 116:125-136.

14. Ding, X. S., Flasinski, S., and Nelson, R. S. 1999. Infection of barley by brome mosaic virus is restricted predominantly to cells in and associated with veins through a temperature-dependent mechanism. Mol. PlantMicrobe Interact. 12:615-623.

15. Ford, R. E., Fagbenle, H., and Stoner, W. N. 1970. New hosts and serological identity of bromegrass mosaic virus from South Dakota. Plant Dis. Rep. 54:191-195.

16. French, C. J., and Elder, M. 1999. Virus particles in guttate and xylem of infected cucumber (Cucumis sativus L.). Ann. Appl. Biol. 134:81-87.

17. French, C. J., Elder, M., and Skelton, F. 1993. Recovering and identifying infectious plant viruses in guttation fluid. HortScience 28:746-747.

18. French, R., and Ahlquist, P. 1988. Characterization and engineering of sequences controlling in vivo synthesis of brome mosaic virus subgenomic RNA. J. Virol. 62:2411-2420.

19. Fritzsche, R. 1975. Transmission of brome mosaic and Arabis mosaic viruses by nematodes in dependence on the infectiveness of host plant roots. Arch. Phytopathol. Pflanzenschutz. 11:197-201.

20. Grignon, N., Touraine, B., and Durand, M. 1989. 6(5) Carboxyfluorescein as a tracer of phloem sap translocation. Am. J. Bot. 76:871-877.

21. Hughes, R. N., and Brimblecombe, P. 1994. Dew and guttation: Formation and environmental significance. Agric. For. Meteorol. 67:173-190.

22. Ishikawa, M., Janda, M., Krol, M. A., and Ahlquist, P. 1997. In vivo DNA expression of functional brome mosaic virus RNA replicons in Saccharomyces cerevisiae. J. Virol. 71:7781-7790.

23. Iyer, L. M., and Hall, T. C. 2000. Virus recovery is induced in Brome mosaic virus p2 transgenic plants showing synchronous complementation and RNA-2-specific silencing. Mol. Plant-Microbe Interact. 13:247-258.

24. Janda, M., and Ahlquist, P. 1993. RNA-dependent replication, transcription, and persistence of brome mosaic virus RNA replicons in S. cerevisiae. Cell 72:961-970.

25. Johnson, J. 1937. Factors relating to the control of ordinary tobacco mosaic. J. Agric. Res. 54:239-273.

26. Kaido, M., Mori, M., Mise, K., Okumo, T., and Furusawa, I. 1995. Inhibition of brome mosaic virus (BMV) amplification in protoplasts from transgenic tobacco plants expressing replicable BMV RNAs. J. Gen. Virol. 76:2827-2833.

27. Kao, C. C., and Ahlquist, P. 1992. Identification of the domains required for direct interaction of the helicase-like and polymerase-like RNA replication proteins of brome mosaic virus. J. Virol. 66:7293-7302.

28. Kerstetter, R. E., Zepp, R. G., and Carreira, L. H. 1998. Peroxidases in grass dew derived from guttation: Possible role in polymerization of soil organic matter. Biogeochemistry 42:311-323.

29. Kiberstis, P. A., Loesch-Fries, L. S., and Hall, T. C. 1981. Viral protein synthesis in barley protoplasts inoculated with native and fractionated brome mosaic virus RNA. Virology 112:804-808.

30. Knoblauch, M., and van Bel, A. J. E. 1998. Sieve tubes in action. Plant Cell 10:35-50. 
31. Kroner, P. A., Young, B. M., and Ahlquist, P. 1990. Analysis of the role of brome mosaic virus 1a protein domains in RNA replication, using linker insertion mutagenesis. J. Virol. 64:6110-6120.

32. Lane, L. C. 1981. Bromoviruses. Pages 333-375 in: Handbook of Plant Virus Infections Comparative Diagnosis. E. Kurstak, ed. Elsevier NorthHolland Biomedical Press, Amsterdam.

33. Levine, A., Tenhaken, R., Dixon, R., and Lamb, C. 1994. $\mathrm{H}_{2} \mathrm{O}_{2}$ from the oxidative burst orchestrates the plant hypersensitive disease resistance response. Cell 79:583-593.

34. Loesch-Fries, L. S., and Hall, T. C. 1980. Synthesis, accumulation and encapsidation of individual brome mosaic virus RNA components in barley protoplasts. J. Gen. Virol. 47:323-332.

35. Lucas, W. J., and Gilbertson, R. L. 1994. Plasmodesmata in relation to viral movement within leaf tissues. Annu. Rev. Phytopathol. 32:387-411.

36. Magwa, M. L., Lindner, W. A., and Brand, J. M. 1993. Guttation fluid peroxidases from Helianthus annuus. Phytochemistry 32:251-253.

37. McKinney, H. H. 1953. New evidence on virus diseases in barley. Plant Dis. Rep. 37:292-295.

38. McKinney, H. H. 1953. Virus diseases of cereal crops. Yearbook of Agriculture 350-360. U.S. Government Printing Office, Washington, D.C.

39. Moline, H. E., and Ford, R. E. 1974. Bromegrass mosaic virus infection of seedling roots of Zea mays, Triticum aestivum, Avena sativa and Hordeum vulgare. Physiol. Plant Pathol. 4:209-217.

40. Nelson, R. S., and van Bel, A. J. E. 1998. The mystery of virus trafficking into, through and out of the vascular tissue. Prog. Bot. 59:476-533.

41. Oertli, J. J. 1962. Loss of boron from plants through guttation. Soil Sci. 94:214-219.

42. Ohmann-Kreutzberg, G., Pawlitschek, W., and Schmidt, H. B. 1960. Eigenschaften des weidelgrasmosaik-virus. Phytopathol. Z. 38:13-17.

43. Oparka, K. J., Roberts, A. G., Boevink, P., Santa Cruz, S., Roberts, I., Pradel, K. S., Imlau, A., Kotlizky, G., Sauer, N., and Epel, B. 1999. Simple, but not branched, plasmodesmata allow the nonspecific trafficking of proteins in developing tobacco leaves. Cell 97:743-754.

44. Paliwal, Y. C. 1970. Electron microscopy of bromegrass mosaic virus in infected leaves. J. Ultrastruct. Res. 30:491-502.
45. Panarin, I. V. 1978. Carrying agents and the mechanism of the spread of the virus of mosaic of smoothe brome grass. S.-Kh. Biol. 2:230-233.

46. Panarin, I. V., and Zabavina, E. S. 1977. Interrelation between Hungarian brome mosaic virus and the vector Oulema melanopa L.: Vzaimootnosheniya virusa mozaiki kostra bezostogo s perenoschikom Oulema melanopa L. Sb. Nauch. Tr. Krasnoyarsk. S.-Kh. Inst. 13:158-159.

47. Quadt, R., and Jaspars, E. M. J. 1990. Purification and characterization of brome mosaic virus RNA-dependent RNA polymerase. Virology 178:189-194.

48. Roberts, A. G., Santa Cruz, S., Roberts, I. M., Prior, D. A. M., Turgeon, R., and Oparka, K. J. 1997. Phloem unloading in sink leaves of Nicotiana benthamiana: Comparison of fluorescent solute with a fluorescent virus. Plant Cell 9:1381-1396.

49. Stawicki, S. S., and Kao, C. C. 1999. Spatial perturbations within an RNA promoter specifically recognized by a viral RNA-dependent RNA polymerase (RdRp) reveal the RdRp can adjust its promoter binding sites. J. Virol. 73:198-204.

50. Sullivan, M. L., and Ahlquist, P. 1997. cis-Acting signals in bromovirus RNA replication and gene expression: Networking with viral proteins and host factors. Sem. Virol. 8:221-230.

51. Thordal-Christensen, H., Zhang, Z., Wei, Y., and Collinge, D. B. 1997. Subcellular localization of $\mathrm{H}_{2} \mathrm{O}_{2}$ in plants. $\mathrm{H}_{2} \mathrm{O}_{2}$ accumulation in papillae and hypersensitive response during the barley-powdery mildew interaction. Plant J. 11:1187-1194.

52. Tiffin, L. O. 1972. Translocation of micronutrients in plants. Pages 199229 in: Micronutrients in Agriculture. J. J. Mortvedt, P. M. Giordano, and W. L. Lindsay, eds. Soil Sci. Soc. Am., Madison, WI.

53. Tosic, M. 1971. Virus diseases of wheat in Serbia. I. Isolation and determination of the wheat streak mosaic virus and brome mosaic virus. Phytopathol. Z. 70:145-162.

54. Tukey, H. B., Jr., and Morgan, J. V. 1962. The occurrence of leaching from above-ground plant parts and the nature of the material leached. Pages 153-159 in: Int. Hortic. Congr., 16th. Brussels, Belgium.

55. Valverde, R. A. 1983. Brome mosaic virus isolates naturally infecting Commelina diffusa and C. communis. Plant Dis. 67:1194-1196. 